\title{
Application of a Methodology Based on the Theory of Constraints in the Sector of Tourism Services
}

\author{
Reyner Pérez-Campdesuñer ${ }^{1}$ (D), Milagros Pérez-Pravia ${ }^{2}$ (D), Alexander Sánchez-Rodríguez ${ }^{1}$ (D), \\ Gelmar García-Vidal ${ }^{1}$ (D), Rodobaldo Martínez-Vivar ${ }^{1}$ \\ ${ }^{1}$ Equinoctial Technological University, campus Santo Domingo (Ecuador) \\ ${ }^{2}$ University of Holguin (Cuba) \\ revner.perez@ute.edu.ec,mpp@_facii.uho.edu.cu,alexander.sanchez@ute.edu.ec,_elmar.garcia@ute.edu.ec, \\ rodobaldo.martines@ute.edu.ec
}

\section{Abstract:}

Purpose: The objective of the research was aimed at achieving the implementation of the theory of constraints on the operating conditions of a hotel, which differs by its characteristics of traditional processes that have applied this method, from the great heterogeneity of resources needed to meet the demand of customers.

Design/methodology/approach: To achieve this purpose, a method of generating conversion equations that allowed to express all the resources of the organization under study depending on the number of customers to serve facilitating comparison between different resources and estimated demand through techniques developed traditional forecasting, these features were integrated into the classical methodology of theory of constraints.

Findings: The application of tools designed for hospitality organizations allowed to demonstrate the applicability of the theory of constraints on entities under conditions different from the usual, develop a set of conversion equations of different resources facilitating comparison with demand and consequently achieve improve levels of efficiency and effectiveness of the organization. 
Originality/value: The originality of the research is summarized in the application of the theory of constraints in a very different from the usual conditions, covering $100 \%$ of the processes and resources in hospitality organizations.

Keywords: theory of constraints, supply chain, logistics decisions, processes management, hospitality organizations

\section{Introduction}

Since 1994 Goldratt published his book "The goal", placing again capability studies as one of the pillars of the administration and kicking off what is now called as Theory of Constraints, applications of this theory they have expanded by different companies and organizations. The theory of constraints has been adopted from two main perspectives: as a general improvement philosophy, which proposes a guide method of thought (Lacerda, Cassel \& Rodrigues, 2010; Rodrigues, Lacerda, Pergher \& Filho, 2012; Banerjee \& Mukhopadhyay, 2016), and focusing on the specific skills upgrading (Chiou, Jhang, Deng, Tsai \& Perng, 2014; Golmohammadi \& Mansouri, 2015; Panizzolo, 2016).

The research reports based on the theory of constraints are different, some are focused on the relationship between organizations that make up logistics chains (Gupta \& Andersen, 2012; Azadnia, Ghorbani \& Arabzad, 2015; Puche, Ponte, Costas, Pino \& de la Fuente, 2016), and others focus on a particular organization (Rezaie, Nazari-Shirkouhi \& Ghodsi, 2010; Dašić, Pešić \& Andelković, 2013; Panizzolo, 2016). The size of the organizations where it is applied is variable, from small entities (Pozo, 2011) to large organizations (Wu, Blos, Wee \& Chen, 2010). The uses of the theory of constraints also have different forms of application, there are some applications for inventory management (Chou, Lu \& Chang, 2010; You \& He, 2010; Chou, Lu \& Tang, 2012), others target planning actions (Kasemset \& Kachitvichyanukul, 2012; Kasemset, Smutkupt \& Anongjanya, 2014; Golmohammadi, 2015) or decisions of product mix (Cannon, Cannon \& Low, 2013; De Souza, Sobreiro, Nagano \& De Souza-Manfrinato, 2013), or the design of control methods (Han \& Lu, 2010; Pergher, Rodrigues \& Lacerda, 2011; Gareev \& Kirshin, 2013).

Despite the diversity and breadth of applications, it can be said that most of these are concentrated in the production sector, since the intangible nature of services raises its complexity to the application, however, several applications are reported in different types of services, among them are: (Groop, Reijonsaari \& Lillrank, 2010; Castaño, Moreira, Sousa \& Meneses, 2013; Kumaran, Othman \& Yusuf, 2015). Particularly in tourism, although there have been reported applications the same, are not as varied although it 
highlights some in such processes as hotels (Dalci \& Kosan, 2012) or restaurants (Alves, dos Santos \& Schmidt, 2014). This is due, among other reasons, because of the nature of this type of service in which coexist different types of resources whose level of existence is necessary to ensure the "product", raison d'etre of the organization, and satisfaction customers, but they do not seem to respond to a single logical or productive flow but the customer makes up their product different way. This article is intended to show the results of application of a methodology in the field of tourism services through conversion, comparison and balance of all resources to ensure the product to the same unit of comparison: the customer satisfaction.

\section{Methodology}

The proposed methodology consists of eight steps each of which is described below.

Step 1. Characterization of the organization is part of achieving a general characterization of the hotel serving entity, identifying its source markets and main processes and capabilities.

Step 2. Demand Forecasting: There must be a demand forecast for customers, applying one of the forecasting methods available, the regression equations are recommended, provided that it can be established influential causes or independent variables that determine the demand is not possible it is recommended that an analysis of time series from identify trends and cyclical characteristics of the series, if not possible then resort methods such as moving average, weighted moving average or exponential smoothing.

Step 3. Identification of potentially restrictive resources. In a hotel in general and in a particular restaurant the amount of resources used is very wide, however not all are essential not come to constitute possible restrictions so it is recommended to use a method of identifying potential restrictive resources as the method $\mathrm{ABC}$ depending on resource demand or costs, or other expert method such as Delphi or kendall.

Step 4. Modeling conversion equations: It is the main step of the methodology, should develop an equation for each resource type. The starting point is to identify all the variables that determine the relationship between the number of customers and the amount of resources needed to deal with, then you must identify the type of relationship between the different variables so that you can determine the amount of resources needed to each type of resource to meet the forecasted demand. For this purpose it should be considered specifically working means as resources can be classified into correspondence with the way they relate to customers, see Table 1. 


\begin{tabular}{|c|c|c|c|c|}
\hline \multicolumn{5}{|c|}{ Classification criteria } \\
\hline & \multicolumn{2}{|c|}{ Way it uses the customer } & \multicolumn{2}{|r|}{ Dynamic means } \\
\hline & Individual & Collectives & Static & Dynamic \\
\hline & $\begin{array}{c}\text { Uses it one person } \\
\text { at a time }\end{array}$ & $\begin{array}{l}\text { It can be used by } \\
\text { more than one } \\
\text { person at a time }\end{array}$ & $\begin{array}{l}\text { Require long-term } \\
\text { maintenance }\end{array}$ & $\begin{array}{l}\text { Cyclically, in short time intervals, they } \\
\text { are subjected to a recycling process to } \\
\text { recover its initial state }\end{array}$ \\
\hline Examples & Chairs & $\begin{array}{c}\text { Tables, table games } \\
\text { and sports }\end{array}$ & $\begin{array}{l}\text { Means cooking, } \\
\text { recycling means, } \\
\text { means for housing }\end{array}$ & Crockery, linen \\
\hline
\end{tabular}

Table 1. Classification of working means

Step 5. Determine capacities available: Once resources are identified restrictive, variables that relate to customers and built the conversion equations proceeds to measure the state of these to replace in the equations and express all resources terms of customers.

Step 6. Determine restriction: Once all resources are already measured or expressed in terms of customers should compare their numbers with customer demand forecast and identify that resource whose availability limits the number of customers to meet and assess their impact on customer satisfaction. That resource whose absence highly unfavorably impact on customer satisfaction and is below the forecasted demand is restricting system.

Step 7. Exploit the constraint: Working with an above restriction affects the sustainability of the system demand in the medium term it is advisable to work the system adjusted to the restriction and control the same in its operation does not exceed or is lower than the restriction so that yields the maximum profit without affecting the sustainability of the system. Ensure this condition is the recommended way to exploit the constraint.

Step 8. Improve the restriction: Identified and exploited the restriction must analyze the causes and generate solutions to increase the restriction to a new level, so as to contribute to promoting continuous improvement. 


\section{Results}

For a better understanding of the methodology it illustrated a hotel application.

Step 1. The entity under study has category three star and has 200 air-conditioned rooms (408 customers), for the food and beverage process serves at the buffet restaurant, a pizzeria and a tavern, and two bars. For the entertainment available: game room, pool, party room, sports grounds.

Step 2. Demand Forecasting: Taking information demand for the past two years and combining forecasting methods based on expert criteria, historical behaviors and volumes of deals established, demand for services was estimated for processes of food and beverages and entertainment, obtaining the results shown in Table 2. The demand for food and beverage process and entertainment process consists of a percentage of the customers of process of lodging and other customers who do not enjoy lodging services but accessing catering services and entertainment through the purchase of additional offers provided by the hotel.

\begin{tabular}{|c|c|c|c|c|c|c|}
\hline \multirow[b]{2}{*}{ Processes } & \multirow{2}{*}{\multicolumn{2}{|c|}{ Areas }} & \multicolumn{4}{|c|}{ Demand } \\
\hline & & & Customers & Another & Total & Estimated \\
\hline \multirow{6}{*}{ Food and beverages } & \multirow{3}{*}{ Bufet restaurant } & Breakfast & 2,460 & & & 3,120 \\
\hline & & Lunch & 1,869 & 600 & 2,469 & 3,120 \\
\hline & & Dinner & 2,460 & 240 & 2,700 & 3,450 \\
\hline & \multicolumn{2}{|c|}{ Pizzeria } & 738 & 45 & 783 & 994 \\
\hline & \multicolumn{2}{|c|}{ Bar } & 443 & 25 & 468 & 594 \\
\hline & \multicolumn{2}{|c|}{ Pool bar } & 623 & 22 & 445 & 817 \\
\hline \multirow{2}{*}{ Entertainment } & \multicolumn{2}{|c|}{ Party hall } & 410 & 821 & 1,231 & 1,563 \\
\hline & \multicolumn{2}{|c|}{ Pool } & 493 & 400 & 893 & 1,134 \\
\hline \multicolumn{3}{|c|}{ Lodging } & 2,460 & & 2,460 & 3,120 \\
\hline
\end{tabular}

Table 2. Demand customer services of food and beverage and entertainment processes

The customer feedback on the perceived level of service were evaluated as well as the trend to new requirements, through analysis of satisfaction surveys applied, proving that there were dissatisfactions regarding the time of providing the service, variety of supply, dishes ran out or were not available, food temperature, incomplete endowment rooms, deficiencies in cleanliness of the rooms and lack of recreational options. All of which affirmed the influence of the physical constraints on customer satisfaction. 
Step 3. Identification of potentially restrictive resources

To identify the resources restrictive analyzed each of the possible resources development using the Delphi method linked to different processes in analysis staff. The results obtained are shown in Table 3.

\begin{tabular}{|c|c|c|c|}
\hline \multirow[b]{2}{*}{ Resource Types } & \multicolumn{3}{|c|}{ Potentially restrictive resources by processes } \\
\hline & Food and beverages & Entertainment & Lodging \\
\hline \multirow{5}{*}{ Supplies } & Salads & & \\
\hline & Seafood & & \\
\hline & Fish & & \\
\hline & Natural fruit & & \\
\hline & Detergents for scrubbing & & \\
\hline \multirow{8}{*}{ Means } & Chairs & \multirow{8}{*}{$\begin{array}{l}\text { Towels higher dimensions } \\
\qquad(120 \times 60 \mathrm{~cm})\end{array}$} & \multirow{5}{*}{ Table games } \\
\hline & Tables & & \\
\hline & Stove & & \\
\hline & Griddle & & \\
\hline & Plastic tanks & & \\
\hline & Glasses of beer & & \multirow{3}{*}{ Sport games } \\
\hline & Wine glasses & & \\
\hline & Dinner plates & & \\
\hline Human Resources & Cooks & Chambermaids & \\
\hline
\end{tabular}

Table 3. Potentially restrictive resources

Step 4 and 5. Modeling conversion equations and determine capacities available: For reasons of space limitations imposed by the publication rules will be explained in an integrated manner these two steps. The conversion equation for each resource type will be presented and analyzed later the results of all similar inputs will be presented.

\section{Supplies for the transformation process:}

For this type of input conversion equation is modeled Expression (1) which further be illustrated by way of example for the fish input.

$$
C S T I=\frac{C H A * V C i * C A * C M T i}{\sum_{j=1}^{n} C P j i * N C i j}
$$


It is:

CSTIi: Customers in the transformation subsystem of input $i$.

CHA: Coefficient of homogenization of the supply, in this case is 3.

$V C i$ : Volume of purchase of input $i$, is $400 \mathrm{~g}$ in this example.

$C M A i$ : Coefficient of reduction of the supply of the input $i, 0.95$ in this case.

CMTi: Coefficient of transformation of input $i, 0.75$ for this example.

$n$ : Possible number of uses of the input in analysis.

$C P i j$ : Preference coefficient of use of the input: it is estimated, taking into account the historical consumption, is calculated by the Expression (2).

NCij: Norm of consumption of the input $i$ in use $j$.

The fish used as input four dishes, each with consumer rules and preferences of different levels, as shown in Table 4.

\begin{tabular}{|c|c|c|}
\hline Dishes & $\begin{array}{l}\text { Consumption Standards } \\
\text { (grams/ dishes) ( } \mathbf{N} C \mathbf{j i})\end{array}$ & $\begin{array}{l}\text { Preference coefficient } \\
\qquad(C P j i)\end{array}$ \\
\hline Grilled wheel of fish & 290 & 0.16 \\
\hline Breaded fish & 250 & 0.20 \\
\hline Canciller fish & 200 & 0.25 \\
\hline Enchilado fish & 250 & 0.07 \\
\hline
\end{tabular}

Table 4. Plates using fish

The coefficient of preference for the use of input i: estimated, given historical use by Equation (2).

$$
C P j i=\frac{\sum_{i=1}^{n} V U P i}{T C P}
$$

It is:

CPji: Preference coefficient of input $i$.

VUPi: Volume of use during the period of the input $i$.

$n$ : Number of ways of using the input $i$.

TCP: Total customers served in the reference period. 
Table 5 shows the results for each of the process inputs food and beverage shown.

\begin{tabular}{|c|r|r|r|r|}
\hline Inputs & Fish & Salad & Natural Fruits & Seafood \\
\hline $\begin{array}{c}\text { Input capacity (Customers in the processing } \\
\text { subsystem (customers / month) }\end{array}$ & 1,831 & 4,825 & 4,025 & 1,286 \\
\hline
\end{tabular}

Table 5. Capacity of the potentially restrictive inputs analyzed

\section{Input for the reuse process:}

The only input used in the reuse process that was considered potentially restrictive detergent for scrubbing this input capacity expressed in customers was determined by the Expression (3).

$$
C S R I=\frac{R j * V D I i}{N C i}=7,500 \text { customers } / \text { month }
$$

It is:

CSRIi: Customers in the reuse subsystem of input $i$.

RCUj: Performance in customers of each use of the input $i$ in the use $j$.

VIi: Available volume of input $i$.

NCUj: Norm of consumption of the input $i$ by use $j$.

$n$ : Ways of using the input $i$.

\section{Working means:}

The working means were considered potentially restrictive were first classified as shown in Table 6 , to determine the type of conversion equation used. The following conversion equations used for each of the types of means analysis are described. 


\begin{tabular}{|c|c|c|c|c|}
\hline Classification & \multicolumn{3}{|c|}{ Subsystems } & Means \\
\hline \multirow{4}{*}{ Static means } & \multirow{3}{*}{ Transformation } & \multicolumn{2}{|c|}{$\begin{array}{l}\text { Preparation/ } \\
\text { Elaboration }\end{array}$} & Stove, griddle \\
\hline & & \multirow{2}{*}{ Services } & Collectives & Chairs \\
\hline & & & Unitarians & Table, table games and sports \\
\hline & \multicolumn{2}{|c|}{ Reusability } & Internal & Plastic tanks \\
\hline Dynamic means & \multicolumn{2}{|c|}{ Transformation } & Services & $\begin{array}{l}\text { Dinner plates, glasses of beer, wine } \\
\text { glasses, towels above dimensions } \\
\qquad(120 \times 60) \mathrm{cm}\end{array}$ \\
\hline
\end{tabular}

Table 6. Classification of potentially restrictive working means in analysis

\section{Conversion equations for static means:}

Static means for the transformation subsystem are analyzed according to the type of process where they are used as described below.

Conversion equation for the preparation and processing. In this case the analysis with the study developed for the stove (4 burners) will be illustrated. The fund time available means (FTAM) is analyzed for the same period when demand (one month) is expressed, considering the length of the workday, loss of time for preparation of jobs and predictable losses from other causes; so the FTAM equals 21,600 min. Table 7 illustrates the steps taken to identify potential customers to cater for medium analysis.

\begin{tabular}{|c|c|c|c|c|}
\hline Dishes & $\begin{array}{l}\text { Standard operation } \\
\text { time (min) }\end{array}$ & $\begin{array}{l}\text { Operation } \\
\text { performance } \\
\text { (customers) }\end{array}$ & $\begin{array}{l}\text { Preference } \\
\text { coefficient }\end{array}$ & $\frac{C p i}{R i} N t$ \\
\hline Stewed beef & 30 & 20 & 0.53 & 0.795 \\
\hline Pork escalope & 20 & 20 & 0.32 & 0.320 \\
\hline Fried pork & 25 & 20 & 0.40 & 0.500 \\
\hline Steak in casserole & 30 & 20 & 0.47 & 0.705 \\
\hline \multicolumn{4}{|c|}{$\sum_{i=2}^{n} \frac{C i}{R i} N t i$} & 12.57 (min/customer) \\
\hline \multicolumn{4}{|c|}{ Fund time available for the working means } & $172,800(\mathrm{~min})$ \\
\hline \multicolumn{4}{|c|}{ Number of working means available } & 4 \\
\hline \multicolumn{4}{|c|}{$C P T M T j=\frac{F T D j * C M D}{\sum_{i=2}^{n} \frac{C i}{R i} N t i}$} & 6,875 (customers) \\
\hline
\end{tabular}

Table 7. Determination of capacity (customers) of working means in analysis 
As shown, the capacity from the stove allows attention of 6,875 customers per month. Using the same equation it is determined that the capacity of the plate is 7,533 customers per month.

\section{Conversion equations for service:}

Conversion equations for chairs. Table 8 shows the estimated time a customer uses the means and time funds for the provision of the service activity. From the above data the Expression 4 was applied.

$$
C S T M T j=\frac{C M D j * T P S j}{T U M S j}
$$

It is:

CSTMTj: Customers in the transformation subsystem of the working means $j$.

$C M D j$ : Number of working means $j$ available.

TPSj: Service time of the working means $j$.

TUMSj: Average time utilization of working means $j$ in service by a customer.

\begin{tabular}{|c|c|r|r|r|}
\hline Number of chairs & Activity & TPS $j$ (min) & TUMS $j$ (min) & \multicolumn{1}{c|}{ Customers/month } \\
\hline \multirow{3}{*}{126} & Breakfast & 4,500 & 40 & 14,175 \\
\cline { 2 - 5 } & Lunch & 5,400 & 90 & 7,560 \\
\cline { 2 - 5 } & Dinner & 5,400 & 90 & 7,560 \\
\hline
\end{tabular}

Table 8 . Data required to determine the customers capacity by activity according to the number of chairs available

Conversion equations for the tables. There were 33 tables available for use, thus applying the Expression (5), the equivalent customers could be served in the restaurant by activity, as shown in Table 9 were determined.

$$
C E j=\frac{C M D j * T P S j}{T U M S j}=5,280 \text { equivalent customers }
$$

It is:

CEj: Equivalent customers of the working means $j$. 
$C M D j$ : Number of working means $j$ available.

TPSj: Service time of the working means $j$.

TUMSj: Average time utilization of working means $j$ in service by a customer.

\begin{tabular}{|c|c|r|r|r|}
\hline Number of tables & Activity & TPS $j(\mathrm{~min})$ & TUMS $\boldsymbol{j}(\mathrm{min})$ & \multicolumn{1}{c|}{ Custumers $/$ month } \\
\hline \multirow{3}{*}{33} & Breakfast & 4,500 & 40 & 3,713 \\
\cline { 2 - 5 } & Lunch & 5,400 & 90 & 1,980 \\
\cline { 2 - 5 } & Dinner & 5,400 & 90 & 1,980 \\
\hline
\end{tabular}

Table 9. Data necessary to identify customers capacity activity according to the number of tables available

The behavior of fundamental customer segments is shown in Table 10, from which was applied to each type of activity the Expression (6).

\begin{tabular}{|l|r|r|r|r|r|}
\hline \multicolumn{1}{|c|}{$\begin{array}{c}\text { Segments } \\
\text { Individual }\end{array}$} & $\begin{array}{c}\text { Segment size } \\
\text { (TSij) }\end{array}$ & $\begin{array}{c}\text { \% historical of } \\
\text { segment } \\
\text { (PHCSij) }\end{array}$ & Type of activity & $\begin{array}{c}\text { Equivalents } \\
\text { customers } \\
(C E j)\end{array}$ & $\begin{array}{c}\text { Number of customers } \\
\text { (customers/month) } \\
\text { (CSTMTj) }\end{array}$ \\
\hline Couples & 1 & 0.16 & Breakfast & 3,713 & 8,912 \\
\hline $\begin{array}{l}\text { Couples with } \\
\text { companions }\end{array}$ & 2 & 0.56 & Lunch & 1,980 & 4,752 \\
\hline
\end{tabular}

Table 10. Behavior of customer segments in the restaurant

$$
C S T M T j=\sum_{i=1}^{n} C E j * T S i j * P H C S i j
$$

It is:

$n$ : Number of segments to be served in the means $j$.

CEj: Customer equivalent of the means $j$.

TSij: Size of segment $i$ to be served in means $j$.

PHCSi: Historical percentage of each customer segment $i$ according to their way of arrival to use the means $j$. 


$$
H C S i=\frac{C S i A j}{T S A j}
$$

It is:

CSiAj: Number of segments $i$ arriving at means $j$.

TSA: Total of segments that can arrive to the means $j$.

With a similar procedure, but for a single hour, it was determined that the capacity of sports games was 5,783 customers per month and table games 4,971 customers per month.

\section{Conversion equation for reuse:}

In the process of reusability were analyzed as potentially restrictive working means of this process plastic tanks, which had a capacity of $6.6 \mathrm{~m}^{3}$, it was determined that daily service operations generated an average $4 \mathrm{~m}^{3}$ of waste. It was estimated that a customer generated $0.01 / \mathrm{m}^{3}$ of waste, the waste was collected every three days, so applying the Expression (8) was determined that existing tanks allow serve 6,660 customers per month.

$$
C S R M T=\frac{C V M R j}{V D C j * C R j}=6,600 \text { customer } / \text { month }
$$

It is:

CSRMT: Customers in the reuse subsystem of working means $j$.

CVMRj: Volumetric capacity of the reuse means $j$.

$V D C j$ : Volume of waste by customers of means $j$.

CRj: Cycle collection for the means $j$.

\section{Conversion equations for rotating means (dynamic):}

Of potentially restrictive means identified: dinner plates, glasses of beer, wine glasses and towels $120 \times 60 \mathrm{~cm}$ above dimensions are considered rotating means. Will be developed as an example dinner plates, they have a standard average consumption of 5 per customer, regardless of the type of activity, existed at the time of the study an availability of 120 plates, was established as service time 14,400 min; 
and a time consuming $25 \mathrm{~min}$ and internal recycling time $30 \mathrm{~min}$; through the Expression (9) it established that the availability of existing dishes could be served 6,284 customers per month.

$$
C S T M T=\frac{C M R i * T S}{N c i *(T C i+T R i)}=6,284 \text { customers } / \text { month }
$$

It is:

CMRj: Available amount of means $j$.

TSj: Service time of the means $j$.

$N C j$ : Standard of consumption of the means $j$ per customer.

TCj: Average of consumption time of the means $j$ by the customer

TRj: Time duration of the internal reuse operation of the means $j$.

Table 11 shows the calculated capacities for other means rotating in analysis.

\begin{tabular}{|c|r|r|r|r|}
\hline Rotating means & Dinner plates & Beer glasses & Wine glasses & $\begin{array}{c}\text { Towels dimensions } \\
120 \times 60 \mathrm{~cm} \text { above }\end{array}$ \\
\hline Capacity (custumers/month) & 6,284 & 5,878 & 7,652 & 3,217 \\
\hline
\end{tabular}

Table 11. Capacities of rotating means

\section{Conversion equations for human resources:}

Charges of potentially restrictive human resources considered were the chambermaids and cooks, for each of these was analyzed differently as shown below.

Conversion equations for the chambermaids. It was considered that organization had seven chambermaids, which have a fund time 13,500 minutes per month, it was estimated that between room cleaning time was 0.37 minutes. Table 12 shows the data necessary to apply the Expression (10) via which states that with existing chambermaids can serve 2,570 customers per month.

$$
C S T R H=\frac{F T D-T D E H-\sum_{i=1}^{4} N t v l i * T H i}{\sum_{i=1}^{4} \% O i *(N t O i+0.6 N t V S i-0.6 N t V L i)}=2,565 \text { customers } / \text { month }
$$


It is:

FTD: Available time fund.

TDEH: Travelling time between rooms.

NtVli: Standard of time for cleaning empty rooms clean.

THi: Total of rooms.

$\% O i$ : Percent occupancy by room type.

NtVSi: Standard of time for the cleaning of dirty empty rooms.

$N \nprec i$ : Standard of time for cleaning occupied rooms.

\begin{tabular}{|c|c|c|c|c|c|}
\hline \multirow{3}{*}{ Room Types } & \multirow{3}{*}{ Amount } & \multirow{3}{*}{$\%$ Occupancy } & \multicolumn{3}{|c|}{ Time standards (min/ room) } \\
\hline & & & \multirow{2}{*}{ Occupied } & \multicolumn{2}{|c|}{ Empty } \\
\hline & & & & Dirty & Clean \\
\hline Simple & 47 & 0.23 & 20.26 & 38.54 & 9.72 \\
\hline Double & 143 & 0.70 & 25.21 & 47.18 & 11.02 \\
\hline Triples & 8 & 0.06 & 29.26 & 44.49 & 11.03 \\
\hline Suite room & 2 & 0.01 & 31.60 & 69.10 & 38.50 \\
\hline
\end{tabular}

Table 12. Data for calculating the amount of customers based on existing chambermaids

Conversion equations for cooks. It had two cooks shift, which should work 27,450 minutes per month, to express the capacity of the cooks to serve customers the Expression (11) was applied.

$$
C S T R H j=\frac{C R H D * F T D}{\sum_{i=1}^{n} \frac{C p i}{R i} N t i}
$$

It is:

CSTRHj: Customers in the transformation subsystem of human resources $j$.

FTDj: Available time fund of human resources $j$.

CRHDj: Number of human resources available for position $j$.

Rij: Performance of the operation $i$ carried out by the human resource $j$.

Cpi: Preference coefficient of operation $i$ in human resource $j$.

Nti: Operation time standard $i$. 
The application of this expression should be considered typical characteristics of each position, for example to use this expression activities critical to consider, considering that these may develop simultaneous or parallel activities were determined. So with the help of a diagram of multiple activities, critical activities were established, considering these as having the longest time standards for each group of activities that are performed in parallel duration. The standard time-critical activities and performance on the customer of these activities and the coefficients of preference for products that these are taxed was followed a procedure similar to that used for chambermaids, establishing a capacity of 8,367 customers to serve in a month.

Step 6. Determine constraint: With information obtained from the above steps were ordered each of the resources, compared with the predicted demands and identifying the critical constraints and current and future potential, the results are summarized in Table 13. According to the results of the input seafood availability was critical current and future capacity. Constraints constituted the following resources: salads, fish, fresh fruit, the stove and plastic tanks. 


\begin{tabular}{|c|c|c|c|c|c|}
\hline Resources & Processes & Activity & $\begin{array}{l}\text { Capacity } \\
\text { customers }\end{array}$ & Demand & $\begin{array}{l}\text { Correlation } \\
\text { coefficient }\end{array}$ \\
\hline Salads & \multirow{16}{*}{$\begin{array}{l}\text { Food and } \\
\text { beverages }\end{array}$} & & 4,025 & 5,169 & 0.78 \\
\hline Seafood & & & 1,286 & 5,169 & 0.25 \\
\hline Fish & & & 1,831 & 5,169 & 0.35 \\
\hline Natural fruit & & & 4,025 & 5,169 & 0.78 \\
\hline Detergent & & & 7,500 & 7,629 & \\
\hline \multirow{3}{*}{ Chair } & & Breakfast & 14,175 & 2,460 & 5.76 \\
\hline & & Lunch & 7,560 & 2,469 & 3.06 \\
\hline & & Dinner & 7,560 & 2,700 & 2.80 \\
\hline \multirow{3}{*}{ Table } & & Breakfast & 8,912 & 2,460 & 3.62 \\
\hline & & Lunch & 4,752 & 2,469 & 1.92 \\
\hline & & Dinner & 4,752 & 2,700 & 1.76 \\
\hline Stove & & & 6,875 & 7,629 & 0.90 \\
\hline \multirow{3}{*}{ Griddle } & & Breakfast & 7,533 & 2,460 & 3.06 \\
\hline & & Lunch & 7,533 & 2,469 & 3.05 \\
\hline & & Dinner & 7,533 & 2,700 & 2.79 \\
\hline Plastic tanks & & & 6,600 & 7,629 & 0.87 \\
\hline \multirow{2}{*}{ Glasses of beer } & \multirow{7}{*}{$\begin{array}{l}\text { Food and } \\
\text { beverages }\end{array}$} & Lunch & 5,878 & 2,469 & 2.38 \\
\hline & & Dinner & 5,878 & 2,700 & 2.18 \\
\hline \multirow{2}{*}{ Wine glasses } & & Lunch & 7,652 & 2,469 & 3.10 \\
\hline & & Dinner & 7,652 & 2,700 & 2.83 \\
\hline \multirow{3}{*}{ Dinner plates } & & Breakfast & 6,284 & 2,460 & 2.55 \\
\hline & & Lunch & 6,284 & 2,469 & 2.55 \\
\hline & & Dinner & 6,284 & 2,700 & 2.33 \\
\hline $\begin{array}{l}\text { Towels above } \\
(120 \times 60) \mathrm{cm} \\
\text { dimensions }\end{array}$ & Lodging & & 3,217 & 2,460 & 1.31 \\
\hline Table games & \multirow{2}{*}{ Entertainment } & & 4,971 & 1,231 & 4.04 \\
\hline Sport games & & & 5,783 & 893 & 6.48 \\
\hline Cooks & $\begin{array}{l}\text { Food and } \\
\text { beverages }\end{array}$ & & 8,367 & 7,629 & 1.10 \\
\hline Chambermaids & Lodging & & 2,568 & 2,460 & 1.04 \\
\hline
\end{tabular}

Table 13. Analysis of constraints

As is observed, the analyzed system does not have a unique demand throughout the logistics flow, this varies from one process to another and within the same processes, according to the diversity of supply that they present; therefore subordinate critical constraints should be established taking into account these peculiarities. It was considered that all existing restrictions should be established as subordinate constraint the means: the stove, but did not show lower coefficient of relationship, if prevented satisfy $10 \%$ of 
demand. Restrictions of other resources to the demand at that time, while affecting customer satisfaction allowed serve $100 \%$ of demand even though the overall satisfaction is affected.

Step 7. Exploit the constraint: To operate the system it was decided to serve the $100 \%$ of lodging customers $(2,460$ customers per month) and 100\% of entertainment customers (2,124 customers per month), and limit the sale buffet restaurant services to external customers, only for lunch on weekends, where they could be served to 30 physical customers. Taken the above decision, an analysis of readjusting purchase volumes of each of the not potentially restrictive resources to schedule the purchase according to the established demand began. What identified the existence of excessive shopping, product such as rice, chicken, mortadella and soda, including those that originated high inventory costs, product wastage in stock and affected the cash flow of the company.

This decision contributed to the organization savings estimated at 1,423.00 USD per month. The means capabilities such as chairs and tables, it was high in correspondence with the demand, however taking into account the architectural structure of the restaurant and future plans of the company it was decided not to make changes in the availability of these means, in the case the griddle although its capacity was too high, there was no possibility of reducing this without affecting the service. Table games, sports and beer glasses, wine glasses and plates even though they were potentially restrictive resources with the application of the procedure was found that these did not constitute constraints for customer satisfaction.

Step 8. Improve constraint: Of the existing constraints, four of them were related to inputs. By delving into the causes established that were determined by the low availability of these resources in the supply of providers, which led to develop a study of suppliers that would improve them and thus establish negotiations with new suppliers, the same so it was necessary to prepare a report of the analysis to the direction of the chain, to request authorization to take these. According to the developed financial analysis it established that the company was financially availability for buying plastic tanks and other stove with capacity similar to the existing cooking as well as existing in the market availability of both products. It was necessary to request authorization from the shareholders of the hotel chain to develop the purchase of stove because at that time were restricted purchases constitute investments. 


\section{Conclusions}

From all the above we can draw the following conclusions:

The validity of the constraint theory does not allow restriction and although its generalization is difficult in the case of services where the products do not follow a single flow and its relation with the final product is diffuse, expressing all the available capacities according to the customers to attend or the forecast of the demand of these facilitates to extend the possibilities of application of the theory beyond the current limits which has been evidenced by the illustrated case study.

Once all the available capacities in a hotel service can be expressed in terms of the same unit of measurement (the customers), it is not only possible to determine the restriction of the service, but it is possible to manage each of the material requirements for the service. Service and be able to vary these in correspondence with the variability of the demand that characterizes the majority of the hotel services.

If the demand forecast is achieved with a long-term strategic vision, knowing the available capacities of each of the resources in the same unit and expressed in the same unit of measure the demand (customers) can allow the management of the physical constraints not only with a tactical or operational vision as shown by the results of this research but also facilitate the strategic management of capacities, which can be used as a starting point for future investment or divestiture plans.

In the management of the physical restrictions of each of the resources involved in hotel services, variables related to: the costs of increasing the resources to increase the number of customers to be served, the degree of satisfaction achieved with the resources available, and how current customer satisfaction would increase if the relationship between capacities, which are not routinely addressed in traditional capacity management, is improved.

\section{References}

Alves, R., dos Santos, J.A.A., \& Schmidt, P.A.C. (2014). Constraints theory and simulation techniques principles apllied in a small restaurant operational dynamics: A case study. Espacios, 35(7), 1.

Azadnia, A.H., Ghorbani, M., \& Arabzad, S.M. (2015). A simulation study on bullwhip effect in supply chain based on theory of constraint. Research Advances in Industrial Engineering, 177-187. https://doi.org/10.1007/978-3-319-17825-7_5 
Banerjee, A., \& Mukhopadhyay, S.K. (2016). A contemporary TOC innovative thinking process in the backdrop of leagile supply chain. Journal of Enterprise Information Management, 29(3), 400-431. https://doi.org/10.1108/JEIM-08-2014-0086

Cannon, J.N., Cannon, H.M., \& Low, J.T. (2013). Modeling Tactical Product-Mix Decisions: A Theory-ofConstraints Approach. Simulation and Gaming, 44(5), 624-644. https://doi.org/10.1177/1046878113503525

Castaño, J.D.M., Moreira, M.R.A., Sousa, P.S.A., \& Meneses, R.F.C. (2013). Theory of constraints in the service sector: Characterization for banking and analysis of the factors involved in its adoption. Lecture Notes in Business Information Processing. 143 LNBIP, 58-72. https://doi.org/10.1007/978-3-642-36356-6_5

Chiou, C.C., Jhang, T.W., Deng, Y.X., Tsai, J.T., \& Perng, C. (2014). Applying lean and TOC to improvement delivery performance for machine tool manufacturers. IEEE International Conference on Industrial Engineering and Engineering Management. https://doi.org/10.1109/ieem.2014.7058779

Chou, Y.C., Lu, C.H., \& Chang, P.L. (2010). Using theory of constraints to find the problem about high level inventory in the aerospace industry. PICMET '10 - Portland International Center for Management of Engineering and Technology, Proceedings - Technology Management for Global Economic Growth.

Chou, Y.C., C. H. Lu, \& Tang, Y.Y. (2012). Identifying inventory problems in the aerospace industry using the theory of constraints. International Journal of Production Research, 50(16), 4686-4698. https://doi.org/10.1080/00207543.2011.631598

Dalci, I., \& Kosan, L. (2012). Theory of Constraints Thinking-Process Tools Facilitate Goal Achievement for Hotel Management: A Case Study of Improving Customer Satisfaction. Journal of Hospitality Marketing and Management, 21(5), 541-568. https://doi.org/10.1080/19368623.2012.626751

Dašić, P., Pešić, M.A., \& Andelković, A. (2013). The theory of constraints as a basis for production process improvement model. Actual Problems of Economics, 148(10), 251-260.

De Souza, F.B., Sobreiro, V.A., Nagano, M.S., \& De Souza-Manfrinato, J.W. (2013). When less is better: Insights from the product mix dilemma from the Theory of Constraints perspective. International Journal of Production Research, 51(19), 5839-5852. https://doi.org/10.1080/00207543.2013.802052

Gareev, B.R., \& Kirshin, I.A. (2013). Theory of constraints in value based cost management. World Applied Sciences Journal, 27(13), 102-106.

Golmohammadi, D. (2015). A study of scheduling under the theory of constraints. International Journal of Production Economics, 165, 38-50. https://doi.org/10.1016/j.ijpe.2015.03.015 
Golmohammadi, D., \& Mansouri, S.A. (2015). Complexity and workload considerations in product mix decisions under the theory of constraints. Naval Research Logistics, 62(5), 357-369. https://doi.org/10.1002/nav.21632

Groop, J., Reijonsaari, K., \& Lillrank, P. (2010). Applying the theory of constraints to health technology assessment. International Journal on Advances in Life Sciences, 2(3-4), 115-124.

Gupta, M., \& Andersen, S. (2012). Revisiting local TOC measures in an internal supply chain: A note. International Journal of Production Research, 50(19), 5363-5371. https://doi.org/10.1080/00207543.2011.627389

Han, X., \& Lu, M. (2010). Research on construction cost control based upon BP neural network and theory of constraint. 2010 International Conference on Management and Service Science, Mass. https://doi.org/10.1109/ICMSS.2010.5576622

Kasemset, C., \& Kachitvichyanukul, V. (2012). A PSO-based procedure for a bi-level multi-objective TOC-based job-shop scheduling problem. International Journal of Operational Research, 14(1), 50-69. https://doi.org/10.1504/IJOR.2012.046343

Kasemset, C., Smutkupt, U., \& Anongjanya, N. (2014). The effectiveness evaluation of job-shop scheduling based on Theory of Constraints (TOC) under demand variation. IEEE International Conference on Industrial Engineering and Engineering Management.

Kumaran, S.R., Othman, M.S., \& Yusuf, L.M. (2015). Applying Theory of Constraints (TOC) in business intelligence of higher education: A case study of postgraduates by research program. Proceedings - 2015 International Conference on Science in Information Technology: Big Data Spectrum for Future Information Economy, ICSITech.

Lacerda, D.P., Cassel, R.A., \& Rodrigues, L.H. (2010). Service process analysis using process engineering and the theory of constraints thinking process. Business Process Management Journal, 16(2), 264-281. https://doi.org/10.1108/14637151011035598

Panizzolo, R. (2016). Theory of constraints (TOC) production and manufacturing performance. International Journal of Industrial Engineering and Management, 7(1), 15-23.

Pergher, I., Rodrigues, L.H., \& Lacerda, D.P. (2011). Theoretical discussion of the concept of wastes in the Toyota Production System: Introducing the throughput logic of the Theory of Constraints. Gestao e Producao, 18(4), 673-686. https://doi.org/10.1590/S0104-530X2011000400001

Pozo, H. (2011). The Theory of Constraints: A case study as a strategic tooling in production management of a small sized company. Espacios, 32(2), 15-17. 
Puche, J., Ponte, B., Costas, J., Pino, R.., \& de la Fuente, D. (2016). Systemic approach to supply chain management through the viable system model and the theory of constraints. Production Planning and Control, 27(5), 421-430. https://doi.org/10.1080/09537287.2015.1132349

Rezaie, K., Nazari-Shirkouhi, S., \& Ghodsi, R. (2010). Theory of constraints and particle swarm optimization approaches for product mix problem decision. Journal of Applied Sciences Research, 6(12), 6483-6491.

Rodrigues, L.H., Lacerda, D.P., Pergher, I., \& Filho, T.A.R. (2012). Application of theory of constraints process thinking to sustainable development: A theoretical proposal. Espacios 33(8), 9.

Wu, S., Blos, M.F., Wee, H.M., \& Chen, Y.L. (2010). Can the toyota way overcome the recent toyota setback? A study based on the theory of constraints. Journal of Advanced Manufacturing Systems, 9(2), 145-156. https://doi.org/10.1142/S0219686710001867

You, J., \& He, S. (2010). Study on optimal model of buffer inventory for the automobile supply chain based on TOC. Proceedings of the International Conference on E-Business and E-Government, ICEE. https://doi.org/10.1109/icee.2010.1155

Journal of Industrial Engineering and Management, 2017 (www.jiem.org)

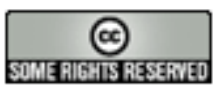

Article's contents are provided on an Attribution-Non Commercial 3.0 Creative commons license. Readers are allowed to copy, distribute and communicate article's contents, provided the author's and Journal of Industrial Engineering and Management's names are included. It must not be used for commercial purposes. To see the complete license contents, please visit http://creativecommons.org/licenses/by-nc/3.0/. 